\title{
Assessment of Home Grown School Feeding Programme (HGSFP) Theory in Kinango Sub-County, Kwale County, Kenya
}

\author{
Kadenge Stephen Karisa ${ }^{1}$ and John Aluko Orodho ${ }^{2}$ \\ Department of Educational Management, Policy and Curriculum Studies, School of Education, Kenyatta \\ University, Kenya. \\ Department of Educational Management, Policy and Curriculum Studies, School of Education, Kenyatta \\ University, Kenya
}

\begin{abstract}
The problematique of this study is that despite the fact that there has been a lot of rhetoric from various stakeholders regarding the perceive direct benefits of the home grown school feeding programme (HGSFP)theory, no systematic research has been conducted to test the theory. This study sought to assess the HGSFP theory in Kinango Sub- county of Kwale County, Kenya. Within this broad perspective, the study examined i) establish theextent to which local farmers were stimulated by the market created by the HGSFP, ii)assess the food security status of the pupils and communities in relation to the presences of the HGSFP in the neighboring primary school in Kanango Sub County. The study used mixed methods incorporating aspects of correlation research and grounded theoretical approaches. A purposive sampling technique was applied to select opinion leaders from cross-sectionof knowledgeable informants from the local community in the study locale. The study established that HGSFP did not directly benefit the local community as was envisaged since majority of people supplyingschool food do not reside from the study locale and instead operated from urban centers. The few local farmers participating in the HGSFP were further constrained with low yields as a result of not using modern agricultural production techniques and stringent procurement procedures. Hencefood security among pupils was not guaranteed due to erratic disbursement of the funds meant for project. It is recommended that the Government through the Ministry of education should sensitize the local community regarding the objectives of the project, and relax the procumbent procedure as an affirmative approach to enable local community actively participate since they can'tfavorably compete with established entrepreneurs in open tendering processes. ( 283 words)
\end{abstract}

Key words: The HGSFP Theory, food sustainability, students, Kinango sub-county, Kenya.

\section{Background Information}

\section{Introduction}

Many children in less developed countries including Kenya suffer from poor health and nutritional problems that impact negatively on their access to, and participation in education (Orodho, 2014). TheUnited Nations estimates that one third of preschool age children in less developedcountries - a total of 180 million children under age 5 - experience growth stuntingrelative to international norms (United Nations, 2000), while hundreds of millions moresuffer from tropical diseases, including malaria and intestinal parasites (OECD,20013; World Health Organization, 2000).

To the extent that poor health and nutrition among children has a negative impact ontheir education, programs or policies that increase children's health status will alsoimprove their education outcomes. Given the importance of education for economicdevelopment (World Bank, 2001), this link could be a key mechanism to improve the quality of life for people in less developed countries such as Kenya (Orodho, 2014). On such mechanism to enhance the health and education of children as well as the socio-economic development of their parents is the home grown school feeding programme (HGSFP) theory. No systematic research has been conducted to test the theory. It is against this backdrop that this study sought to assess the HGSFP theory in Kinango Sub- county of Kwale County, Kenya.

\section{State of literature}

According to Neeser (2012), 60 million children go to school hungry every day in developing countries; children that don't eat don't learn. Tomlinson (2007) and Glewwe.et.al (2008) add that health and education are the two cornerstones of human capital and form the basis of an individual's economic productivity. Both are valuable instruments in ensuring a healthy economy and creating a literate society. Kiamba, (2013) citing the WFP, (2009) and (UNESCO, 2011) says 66 million school children are undernourished and an additional 67 million children are out of school. According to Otsuki (2011), securing adequate quantity and quality of food for school meals is vital to achieving education for all, because in many 
developing countries, the school meal is the main - if not the only - meal of the day for many schoolchildren. Good quality school food guarantees school attendance and good educational outcomes. Espejo, Burbano and Galliano, (2009) say that school feeding, in its variant forms, is a well-recognized programme that alleviates hunger while supporting education, health and community development. Neeser, (2012) says healthy children learn better. School health and nutrition (SHN) interventions have been shown to improve not only children's health and nutrition, but also their learning potential and life choices both in the short- and long-term. The school feeding programme in Brazil according to Otsuki and Arce (2007) is part of the framework of food security policy and aims to reduce the number of malnourished children and the need to provide healthy, good quality food for children as a means to improve the population's eating habits - nearly 40 percent of the population is overweight and 5 percent is obese. Tomlinson (2007) in his study of the feeding programmes in Malawi and Zambiasays that there is an association between low-achieving children and less regular breakfast meals. Deficiencies in micronutrient have been associated with poor performance on various achievement tests. School feeding is positively correlated with infant mortality rates - a one percent decrease in infant mortality levels for every extra year of schooling for a mother - to - be.

School feeding, according to Espejo, et al (2009) has been an effective safety net that can prevent those affected by economic shocks (increased food prices or during protracted crises) from adopting negative coping strategies. School feeding is currently being used in this way in many countries, including Haiti, Liberia, Pakistan and Senegal. In many low-income countries, school feeding programmes have also been a critical part of the response to the global economic crisis, (Neeser, 2012). The objectives of school feeding vary depending on the context. General objectives are to: meet the immediate food needs of children; alleviate short-term hunger and improve learning capacity; increase access to education (i.e. enrolment, attendance, retention and completion); reduce gender and social inequalities; improve health and nutrition status; increase development opportunities, (Espejo, et al, 2009). However, citing The World Bank, Tomlinson (2007) argues that there is little evidence that school feeding programmes have a positive impact on nutrition neither for participating children nor on the root causes of malnutrition and hunger

Kiamba (2013) says that in 2003, NEPAD, in collaboration with WFP and the Millennium Hunger Task Force launched the Home Grown School Feeding and Health Programme initiative. The concept is based on harnessing structured demand from school food provision ( a win- win for farmers and school children). Tomlinson (2007) advocates for the use of SFP not for educational benefits per se but as developmental tool saying it would focus on improving the livelihoods of particular groups that are vulnerable to food insecurity, and not simply (for example) improving school enrolment. The author goes on to argument that, if increased enrolment is the aim, then using government funds to reduce or waive school fees would be a more costeffective way of ensuring this than an SFP. The SFP should be seen as income transfer within the community and not solely on school feeding. In Otsuki (2011), the Home Grown School Feeding Programme initiative is an institutional experiment in promoting a green economy by linking public sector food procurement to sustainable agriculture. HGSF is a school feeding programme that offers food produced and purchased within a country. The focus is to produce and purchase food for the school feeding programme from local small-scale farmers, (Espejo et al, 2009).

Songa (2011) says the need to transit from SFP to HGSF was after the quest for reduced costs, a more sustainable feeding programme, provision of predictable market for local farmers, boost local development and to enhance local ownership of school meals programme. The overarching objectives of the HGSFP is to act as a vehicle for promoting local development and fighting food and nutrition insecurity, disease and to stimulate agriculture production and development by linking local small producers to markets (schools). Within education, just like the previous SFP, the purpose of HGSF is to increase enrolment, promote regular school attendance and retention; improve children's learning capacity, and learning outcomes, and enhance gender equality. However, the HGSFP has a component for farmers and community stakeholders: improved food security, including food availability, access and utilization(Espejo, et al 2009; Songa, 2011; Kiamba, 2013). In the opinion of Neeser (2012), the advantages of linking local agriculture and school feeding are substantial: more prosperous smallholder farmers, with a more secure future; stronger rural communities, with more stable economies; increased demand for local, fresh food; and healthier, happier children. PCD (2012) adds create job opportunities for cooks to the objectives of the OSHGSFHP in Nigeria. In the case of the feeding programme in Thailand, Kanemasu (2007) says one of the objectives was to shield farmers from international competition.

School feeding programs in Kenya have been in place since 1980s, primarily to incentivize the enrollment and retention of rural children and girls, and to contribute to realization of universal primary education, (Langinger, 2011; Bodo, 2012; Reche, Bundi, Riungu \& Mbugua, 2012). According to Langinger (2011), the programmes have been heavily relying on foreign aid and management, often conditional. This has limited the Kenyan government's role in the direction and stewardship of these programs. Kenya was one of the countries to pilot NEPAD supported HGSFP in 2009 in an effort to transition toward a more sustainable and nationally integrated school feeding alternative and in particular shift the financial responsibility. However, 
financial strains and infrastructural challenges have put in doubt Kenya's ability to successfully fund and operate its own school feeding program. In 2009, 500,000 primary school children were transferred over from WFP programmes to HGSFP, and promised to add 50,000 students each year until reaching full coverage (Finan 2010). Before this move, 71 percent of program costs were provided by WFP, 15 percent was local communities' obligation, and only 14 percent came from the Kenyan government (Galloway 2009). To ensure success of the new program, the Kenyan government allocated \$5.3 million and \$2 million from the Japanese government meet the programme. In the new program, cash stipends transfers are made twice at the beginning of each three-month term, directly into the bank accounts of participating schools to be applied to the program (Finan 2010). The amount is determined by net student enrollment at nine cents per student meal - about half of what WFP spent per meal (USDA 2009). Bodo (2012) says HGSFP has been found to empower the community as food products are sourced locally. However the author did not provide data for this position.

\section{Problem statement and Justification}

Despite the fact that investing in nutrition related programme is not a luxury in today's world, and that research evidence demonstrates the importance of food and nutrition to intellectual and educational development, no systematic studies have been made in Kenya to empirically provide credible evidence. Yet, there is a lot of rhetoric from researchers, programme initiators, sponsors and politicians on the perceived direct benefits to the locals of the HGSFP without tangible data on the claims that the programme, introduced in 2008 - 2009 has been able to achieve its objectives. While the contribution of HGSFP and its predecessor, SFP, to enrolment, attendance, and learning outcomes is well is not contestable and is well documented across the globe, very few studies have attempted to demonstrate the extent to which HGSFP has been able to improve if not transform the agricultural mindset and economic situation and the lives of the communities living in the immediate neigbouhood of the schools where the programme is present. The researcher in this study wanted to establish how the local farmer had benefited directly from the programme by doing business with the school as individuals or cooperatives as this was the main thrust for changing from SFP to HGSFP.

The justification of this study is hinged on the unique socio-economic and geographical situation of Kinango Sub County in Kinango County. Kinango sub-county is the dry part of Kwale located to the north of Kwale County, and occupies sections along Nairobi-Mombasa highway, spreading from Ndi, Samburu, to Mariakani and Mazeras. To the west, the sub county spreads up to the Kenya-Tanzania border, southwards of Taveta. According to Mutuku, King, Mungai, Mbogo, Mwangangi, Muchiri, Walker, and Kitron, (2011), the rainfall in coastal Kenya including Kinango is bimodal, with a long rainy season in March-June and an unpredictable shorter rainy season in October-December. A cooler, dry season, also highly unpredictable, in July-September and the hot and dry season is between January and March. In 2009 both rainy seasons were below average, the short rainy season in failed altogether in 2010 . The average rainfall for the 18 -year period of 1993-2010 was 1,431.0 mm (1,323.0 mm excluding the El Niño year of 1997). There were two clear drought cycles during the 2000-2010 periods, but no easily discernable ones in 1993-1999. Generally, Kinango is dry, and not suitable for vibrant agricultural practices. The main activity is subsistence farming, constantly threatened by extremely erratic rains. Land in Kinango is communally owned, with a few ranches. The agriculture is mostly rain fed; crop production is scarce, due to poor rainfall, under development, poor infrastructure. Livestock production is characterized by local breeds of beef cows, goats and sheep.

Consequently, the residents rely heavily on food relief for most parts of the year. The most vulnerable groups to food insecurity include persons with disabilities, children in need of special protection, people living with HIV, and female-headed households that comprise approximately 30 per cent of the population. According to Aga Khan Foundation (2010), the district registers very low health and development outcomes: maternal mortality rate is 650 deaths per every 100,000 live births; infant mortality rates is 92 deaths out of every 1000 live births; child mortality rate is 149 deaths per every 1000 live births, and under five morality rate is 118 per 1000 live births. Absolute poverty rates in the district stand at 75 percent (163,754 of the population). The district's contribution to the provincial poverty is about 8.8 percent (Kinango district development plan, 2008:33). According to ILO (2010) there are more than 2000 orphans and vulnerable children in the sub county, with about $17 \%$ and $2.9 \%$ not living with their biological fathers and mothers respectively. On family status, the study showed that in Kinango, death/absence of fathers was high; $15.3 \%$ of all mothers were either widowed (7.2\%) or single (8.1\%). These outcomes place Kinango district off the track in attaining the Millennium Development goals and Kenya's Vision 2030, thus making it vulnerable to external and external shocks that need proper planning of appropriate programmes geared towards the alleviation the multiple problems being experienced in the sub-county.

\section{Purpose and objectives of the study}

The purpose of the study reported in this paper was to test the efficacy of the homegrown school feeding programme (HGSFP). The study was guided by the following objectives: 
i. To establish the actual source of the food prepared for pupils in the schools participating in HGSFP in relation to the objectives HGSFP in Kinango Sub County

ii. To establish whether there was a crop acreage change among the local farmers as stimulated by the market created by the HGSFP in Kinango Sub County

iii. To establish the food security status of the pupils and communities in relation to the presences of the HGSFP in the neighbouring primary school in Kinango Sub County

The HGSFP Theoretical Framework

The study was based on the HGSFP Theory postulated Bundy, Burbano, Grosh, Gelli, Jukes, and Drake in 2009 as illustrated in Figure1.
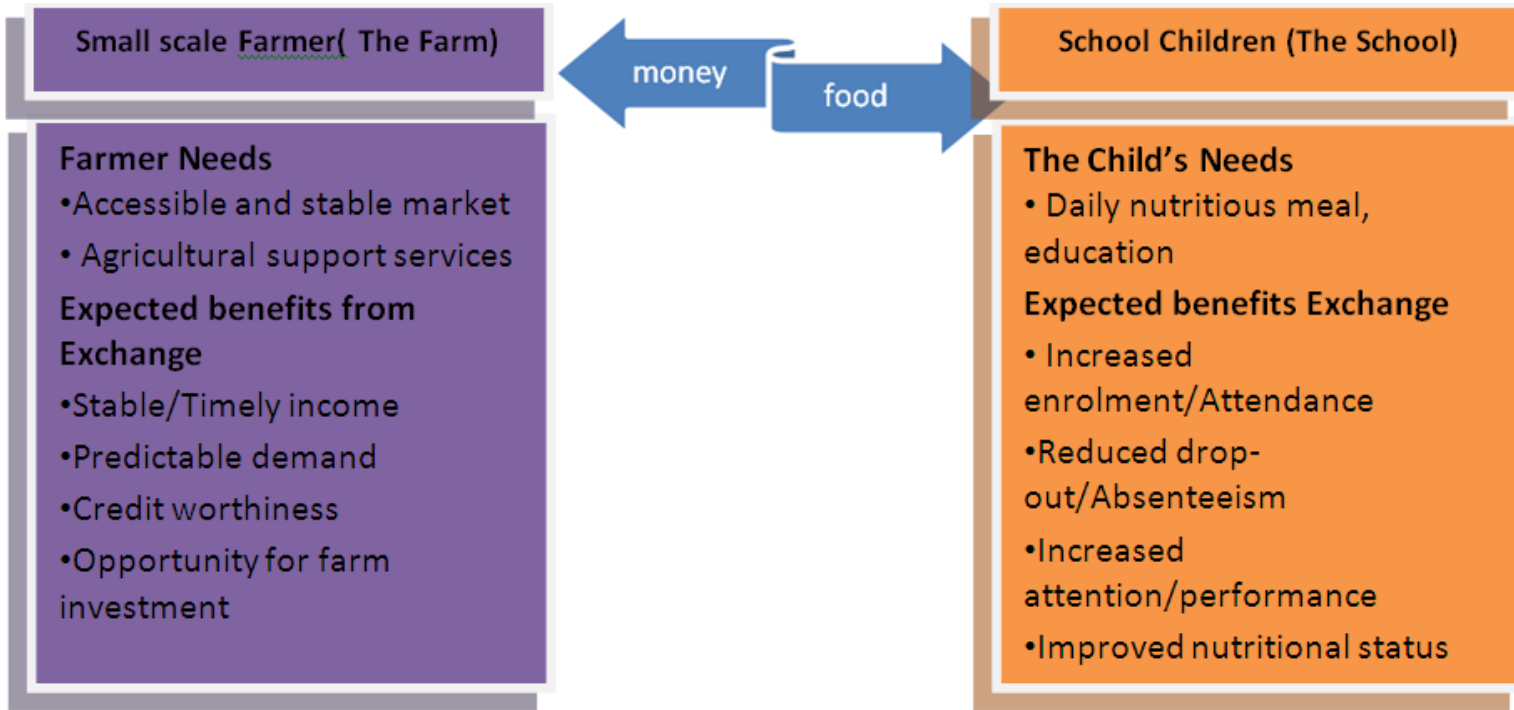

Figure 1: The major components of the HGSFP Theory

Mumuni (2012) and Kiamba (2013) explain this theory by saying that HGSFP has three target groups: school children, the small scale farmers (food production) and the community stakeholders across gender dimension (food preparation jobs opportunities, food security). The theory suggests several societal developmental changes as induced by HGSFP including several potential benefits and opportunities: School feeding creates additional demand for food commodities - a demand driven development intervention; provides a stable and predictable market for farmers to access; reducing risk and increasing investment behavior and overcomes barriers to market entry.

With regards to the target of HGSFP, Espejo et al (2009), assert that while school feeding programmes principally target school-age children, HGSF programmes target small-scale farmers - who are mostly poor because of inadequate access to assets such as land, water and human capital. Their production practices are characterized by limited use of productivity-enhancing technologies and practices - such as hybrid seeds and fertilizers. They are also poor because even when they do adopt improved production methods, they are often unable to easily sell their produce in markets, which, for smallholders, are thin, volatile and costly. It is theorized that that HGSF programmes can deliver a wide variety of outcomes, have the potential to trigger development processes that benefit not only children in schools, but the community as a whole; it becomes a development tool at the community and country levels.

This theory was used alongside the three-stage framework or model of transition from SFP to HGSFP by Espejo et al (2009). The model suggests that buying food from small-scale farmers does not happen automatically or suddenly, rather, it happens incrementally over three stages. The programme evolves depending on the specific context and capacities of the different stakeholders involved. HGSF is conceptualized as a process that can take many years to complete, requires flexibility to adapt to changing situations and to manage the risks and challenges that might arise. The first stage is characterized by a relatively small proportion of food purchased from small scale farmers. The rest of the requirements are bought through normal practices. The aim is to create an enabling environment for smallholders to start accessing the school feeding market. The second stage is Agricultural Development. This stage focuses on increasing the proportion of food purchased from smallholders, without sacrificing the quality, quantity and timeliness of the food being delivered to schools. This stage depends on the extent to which agricultural production is increased. The third stage is Institutional and Policy Development. This stage focuses on developing sufficient capacity to be able to rely on 
small-scale farmers' self-initiated response without sacrificing the quality, quantity and timeliness of food being delivered to the schools.

\section{Research Methodology}

The study was mixed methods design in that it had aspects correlational design and grounded theory design. According to Creswel (2012) and Orodho (2012) this design is the best as it captures the advantages of quantitative methods and qualitative methods. The correlation part focused association and relationship between farmers' acreage and the introduction of the programme by observing the direction and strength of the acreages before and after the introduction of HGSFP. The researcher used simple random sampling to select 12 schools out of the 36 schools in the sub county. From the sampled schools, the researcher conducted focused group discussion (FGD) with various opinion leaders from the community around the school.. The community members were selected using purposive sampling and included the Village chairman, the School Management Committee Chairman, two parents and one business person. The discussion was centered on the sourcing and production of the food.This formed the basis of the grounded theory design. The researcher also developed a questionnaire that was administered to the head teachers. It captured data on the financing and procurement aspect of HGSFP. The data was analysed using Pearson Correlation.

\section{Source of food cooked in HGSFP}

\section{Findings And Discussion}

The researcher asked the head teachers to state where they obtained the food that were cooked for the pupils in the school. Several options were given and the responses are as captured in Table 1.

Table 1 : The source of food cooked for the pupils

\begin{tabular}{|c|c|c|c|}
\hline Response & Frequency & Percent & $\begin{array}{l}\text { Cumulative } \\
\text { Percent }\end{array}$ \\
\hline Neighbouring shops & 1 & 8.3 & 8.3 \\
\hline Local Farmers around the school & 1 & 8.3 & 16.7 \\
\hline From NGOs like WFP & 1 & 8.3 & 25.0 \\
\hline Tendered suppliers & 9 & 75.0 & 100.0 \\
\hline Total & 100.0 & & \\
\hline
\end{tabular}

From the table, it is evident that the food was procured from tendered suppliers -75 percent. Tendered supplying is open to all and sundry hence this finding suggests that the food is not obtained from the local farmers but to any business person from anywhere. Even the local shops are not given the opportunity to trade with the school. This implies that the vision of having the HGSFP money to circulating among the locals as a way of improving their economic status cannot be realized.

\section{Process of procuring the food}

As a follow up question, the head teachers were asked to state the process which they used in buying the food from the source that they had identified. The purpose of this question was to establish whether there was an affirmative action to give priority to local farmers and business people from around the schools. The responses are given in Table 2 .

Table 3.2 :Food Procurement Process

\begin{tabular}{llll}
\hline Response & Frequency & Percent & Cumulative Percent \\
\hline Direct purchase from individual farmers & 1 & 8.3 & 8.3 \\
Direct Purchase from neighboring shops & 3 & 25.0 & 33.3 \\
Through bidder suppliers & 7 & 58.3 & 91.7 \\
Direct purchase from organized farmers groups & & & \\
& 1 & 8.3 & 100.0 \\
\hline Total & $\mathbf{1 2}$ & $\mathbf{1 0 0 . 0}$ & \\
\hline
\end{tabular}

From the table it is clear that there is no effort from the head teachers to ensure that the community around the schools is empowered economically through the HGSFP. The bulk of the food -58.3 percent - is procured through open tenders. Given the level of poverty among the people, it is less likely that the suppliers are from the local area. Only 16.6 percent of the food is bought from either individual farmers or organized farmers' groups. This defeats the objectives and theory of HGSFP as espoused by Bundy, et al (2009). It also contradicts Bodo (2012) who had indicated that the programme had empowered the local community.

The HGSFP as a stimulant to agricultural Productivity 
The HGSFP theory posits that the presence of the programme is bound to stimulate an increase in agricultural production among local farmers because the farmers wouldn't have difficulties selling their farm produce. In order to test this aspect of the theory, the researcher asked the local people some questions regarding their agricultural activities.

\section{Type of food crop grown}

In the course of the study, the researcher established through observation that the food that was prepared for the pupils was a mixture of maize and beans, popularly known as githeri. The researcher therefore wanted to find out if this was the staple food among the community and whether the farmers grew this crop. The responses are given in Table 3.

Table 3: Main food crop grown

\begin{tabular}{llll}
\hline Response & Frequency & Percent & $\begin{array}{l}\text { Cumulative } \\
\text { Percent }\end{array}$ \\
\hline Maize & 9 & 75.0 & 75.0 \\
Millet & 1 & 8.3 & 83.3 \\
Rice & 2 & 16.7 & 100.0 \\
\hline Total & $\mathbf{1 2}$ & $\mathbf{1 0 0 . 0}$ & \\
\hline
\end{tabular}

From table 3, majority of the farmers comprising 75 percent grow maize, which is an ingredient of the food that the schools prepare. This implies that there is an opportunity to encourage the farmers to grow more maize since the market is readily available among the schools. This finding is in line with the HGSFP theory which encourages local food to be used in the programme to stimulate intensive farming of that local crop, (Espejo et al, 2009; Mumuni, 2012; Kiamba, 2013).

\section{Community awareness to the HGSFP Opportunity}

The researcher wanted to establish whether the community was aware that they had an opportunity to improve on their economic status by growing more maize and other food crops to be sold to the school as required by the programme. The responses are given in Table 4.

Table 4: Awareness of the HGSFP opportunity

\begin{tabular}{llll}
\hline Response & Frequency & Percent & $\begin{array}{l}\text { Cumulative } \\
\text { Percent }\end{array}$ \\
\hline Yes & 4 & 33.3 & 33.3 \\
No & 3 & 25.0 & 58.3 \\
I don't know what you are talking & 5 & 41.7 & 100.0 \\
about & $\mathbf{1 2}$ & $\mathbf{1 0 0 . 0}$ & \\
\hline Total &
\end{tabular}

From the responses in Table 4, it is revealed that majority of locals constituting two thirds of the locals were not aware of this opportunity. In fact it was surprising that 41.7 percent had not heard of the HGSFP and what it was all about. However, from the FGDs, the researchers were noted that the people who were aware of the programme were the SMC Chairmen.

The researcher further asked the respondents in the FGDs whether they had been approached by the school administration to sell some food stuff to the school. The findings are given in Table 5.

Table 5: Level of Opportunity to sell food to the school

\begin{tabular}{llll}
\hline & & & $\begin{array}{l}\text { Cumulative } \\
\text { Percent }\end{array}$ \\
\hline Yes & Frequency & Percent & 16.7 \\
No & 2 & 16.7 & 91.7 \\
No but I have heard about it & 1 & 75.0 & 100.0 \\
\hline Total & $\mathbf{1 2}$ & 8.3 & \\
\hline
\end{tabular}

From the table 5, it is evident that majority, constituting 83.3 percent of the respondents had not been given the opportunity sell their food stuff to the schools. This finding suggests that the school administration and management did not disseminate to the community the opportunities presented to them by the programme. Thus it can be concluded that should the programme fail to realize its objectives, part of the blame should go to the school management.

\section{Food crop acreage after introduction of HGSF}

The researcher asked to respondents in the FGDs to state the acreage of their farms that was under maize in 2009 (before the inception of HGSFP) and 2013 (during HGSFP). The researcher then ran Pearson 
correlation to test the strength and direction of the means of maize production between the two periods. The findings were; $\mathrm{r}=0.483 ; \mathrm{n}=12 ; \alpha=.05$; two tailed; $\mathrm{df}=10$; critical $\mathrm{r}=0.576$. Given that the calculate $\mathrm{r}$ is less than the critical $r$; the researcher concluded that there was no relationship between the acreage of farm under maize and the introduction of HGSFP.

\section{Food security after Introduction of HGSFP}

The researcher asked the respondents in the FGDs whether they still had problems with feeding their families and if they looked for and scrambled for relief food. The responses to this question were correlated with the responses as to the question on whether they were aware of the HGSFP opportunity. The findings were; $r=$ $0.118 ; \mathrm{n}=12 ; \alpha=.05$; two tailed; $\mathrm{df}=10$; critical $\mathrm{r}=0.576$. Given that the calculate $\mathrm{r}$ is less than the critical $\mathrm{r}$; the researcher concluded that there was no relationship between the food security in the community and knowledge of the existence of the HGSFP.

The findings of this study are in tandem with Espejo et.al.(2009) who writing on HGSFP asserted that while school feeding programmes principally target school-age children, HGSF programmes target small-scale farmers - who are mostly poor because of inadequate access to assets such as land, water and human capital. Their production practices are characterized by limited use of productivity-enhancing technologies and practices - such as hybrid seeds and fertilizers. They are also poor because even when they do adopt improved production methods, they are often unable to easily sell their produce in markets, which, for smallholders, are thin, volatile and costly.

The foregoing notwithstanding, the widely theorized notion that HGSF programmes can deliver a wide variety of outcomes, and have the potential to trigger development processes that benefit not only children in schools, but the community as a whole seemed not to be working in the study locale. It was evident that HGSFP had not become a development tool at the community and country levels contrary to its overdramatized envisaged expectation.

\section{Conclusion And Recommendations}

The gist of this study was to test the efficacy of the HGSFP in the study locale. From results emanating from the study, it is concludes that the HGSFP has not achieved its objectives in Kinango Sub-county of Kwale County in Kenya. HGSFP has not stimulated the local economy and nor financially empowered the community. It has not even encourage local procurement as found by Langinger (2011). The HGSFP in Kinango largely benefits the bigger business people who do not reside among the locals but operate their businesses in the urban centers and townships. The funds released by the government towards the programme which was meant to circulate among the locals and improve their economic status do not reach the intended people; and instead ended in lining up the pockets of already rich people.

The farmers in the area have not been stimulated by HGSFP to grow more maize and beans to sell to the schools. The farmers are still using their usual ways in agricultural activities. There is no adaptation of innovative ways of improving farm productivity. The main reason is that the schools have not shared this opportunity with the community. The community is not aware that they can do business with the schools. Because of this the farm acreage under maize has remained constant before and after the introduction of HGSFP.

Food security has also not improved among the community members. The locals still depend on rain fed agriculture and poor farming techniques leading to low harvests. The local hardly harvest enough to last them the whole year hence they have to rely on food aid from organizations like Red Cross, World Vision, and Government relief among other food donor agencies. Food security among the pupils is also not guaranteed because of the erratic disbursement of HGSFP money by the government.

From the foregoing discussion, it is recommended that: First, the Government of Kenya, through the Ministry of Education should work out mechanisms of ensuring the school administration hold regularparents meetings to sensitize the community on the opportunity provided through the HGSFP.

Secondly, The Government of Kenya through The Department of Education in conjunction with the Department of finance relaxes the procurement procedure for HGSFP food as an affirmative action to enable the schools to buy directly from the farmers - even if in small quantities - since most farmers cannot compete favorably in open tenders.

Finally, the Government of the Republic of Kenya through the Department of agriculture in conjunction with that of water resource development should put in place strategies that empower the local community and encourage them to embrace group irrigation farming so that the farmers can be provided with irrigation equipment and skills, have a common pool of food produce and became less dependent on rain fed agriculture.

\section{References}


[1]. Aga Khan Foundation. (2010).Coastal Rural Support Programme Kenya Pro-Poor Integrity Project: Local Government Partnership Survey Report. Nairobi: Strapola Mala

[2]. Bodo, S. (2012).Education in Reconstruction: Kenya - A Working Brief. Tunis Belvédéré; Association for the Development of Education in Africa (ADEA)/African Development Bank (AfDB)

[3]. Bundy, D., Burbano, C., Grosh M., Gelli, A., Jukes, M. \&Drake, L. (2009).Rethinking School Feeding: Social Safety Nets, Child Development, and the Education Sector. Directions in Development Series. Washington, DC: World Bank.

[4]. Espejo, F., Burbano C., \&Galliano, E. (2009). Home-grown School Feeding: A Framework to Link School Feeding with Local Agricultural Production. Rome: World Food Programme

[5]. Finan, T,. (2010). Impact Evaluation of WFP School Feeding Programmes in Kenya (1999-2008): A Mixed-Methods Approach. Rome: World Food Programme

[6]. ILO. (2010).Micro Factors Inhibiting Education Access, Retention and Completion by Children from Vulnerable Communities in Kenya: Final Report. ILO's International Programme on the Elimination of Child Labour (IPEC).- ISBN: 978-92-2-127128-4 (Web PDF).

[7]. Kanemasu, Y. (2007).Thailand: a desk review of the school feeding programmes Cardiff; World Food Programme

[8]. Kiamba J. (2013) Workshop, ECA Linking Nutrition to agriculture through school Feeding; CAADP Nutrition. Dar es Salaam, PCD 25 Feb-1 March 2013

[9]. Langinger N. (2011) School Feeding Programme in Kenya: Transition to a Homegrown Approach. In Stanford Journal of International relations Vol XIII No.1

[10]. Mumuni D. (2012): Home Grown School Feeding: Hamburg, Partnership for Child Development (PCD)

[11]. Mutuku F. M., King C.H., Mungai P., Mbogo, C., Mwangangi, J., Muchiri E.M., Walker, E. D., \& Kitron, U. (2011). Impact of insecticide-treated bed nets on malaria transmission indices on the south coast of Kenya. Malar J. 2011; 10: 356. doi: $10.1186 / 1475-2875-10-356$

[12]. Neeser K. (2012) Home Grown School Feeding Smallholder Farmers Providing Local Food for Local Children; Imperial College London

[13]. Office of the President, (2007) Drought Monitoring Bulletin: Kwale/ KinangoDistrict. http://reliefweb.int/sites/reliefweb.int/files/resources/BB3F0FB196C7304EC12573610035EAB0-Full Report.pdf.

[14]. Odhiambo.D. (2010). Task force on re-alignment of education to the Constitution 2010 and Vision 2030 and beyond. The Government of Kenya.

[15]. OECD (2013).Ensuring fragile states are not left behind: Fact sheet on resource flow and trends .http://www.oecd.org.

[16]. Oketch, M. \&Ngware, M. W . (Eds.). (2012).urbanization and Education in East n Africa: African Population and Health Research Center. ISBN 978-9966-21-175-0

[17]. Otsuki K., (2011) Home-grown Food in Schools for a Green Economy. United Nations University

[18]. Otsuki, K. \&Arce A. (2007). Braziila: Desk Review of the National School Feeding Programme.

[19]. Orodho,A.J.(2014).Triumphs, Prospects and Challenges in Coalescing nutrition and Health programmes to Enhance Participation in Basic Education as a Panacea to Socio-Economic Development of Marginalized Communities in Kenya in the $21^{\text {st }}$ Century. Paper presented at the Nutrition and Education Conference, March $9^{\text {th }}$ to $14^{\text {th }} 2014$, North Coast Beach Hotel, Kilifi County, Kenya.

[20]. PCD .(2012) .Osun State Home Grown School Feeding and Health Programme Case study Home Grown School Feeding in Nigeria .

[21]. Reche, G.N.,Bundi,T.K, .Riungu,J,N,.\& Mbugua, Z.K (2012).Factors contributing to poor performance in Kenya Certificate of Primary Education Examinations in Public Primary SCHOOLS IN Mwimbi Division, Maara District, Kenya. International Journal of Humanities and Social Sciences. Vol,5 March, 2012.

[22]. Songa, L. (2011). School Feeding Programmes in Kenya: Leveraging Agriculture for Improved Nutrition \& Health International conference: New Delhi India 10-12 February, 2011

[23]. Tomlinson M. (2007) School Feeding in East and Southern Africa: Improving Food Sovereignty or Photo Opportunity?Regional Network for Equity in Health in Southern Africa (EQUINET). EQUINET Discussion Paper Number 46 - March 2007.

[24]. United Nations.(2000). IACC/SCN $4^{\mathrm{TH}}$ Report on the worlds nutrition situation. Washington DC ( In collaboration with international food policy Research Institute).

[25]. World Health Organization.(2000).The World Health Report 2000. Geneva. 